ISSN 2455-2550

DOI: http://dx.doi.org/10.20431/2455-2550.0202003

www.arcjournals.org

\title{
The Impact of Olive Seeds (Olea europaea L.) Powder (OSP) and its Nanoparticles (NOS) on Obese Hyperlipidemic Rats
}

\author{
Mohamed S.M.E. Abdelbaky ${ }^{1}$, Hoda S. Ibrahim ${ }^{2}$, Mohamed L. Hassan ${ }^{3}$, \\ Zahraa E. Sayed ${ }^{4}$ \\ ${ }^{1,2}$ Professor of Nutrition at Nutrition and Food Science dept., Faculty of Home Economics, \\ Helwan Univesity. Egypt \\ ${ }^{3}$ Professor at Department of cellulose - National Center for Research \\ ${ }^{4}$ Ph.D Researcher at Nutrition and Food Science dept., Faculty of Home Economics, \\ Helwan Univesity. Egypt
}

\begin{abstract}
This study was carried out to investigate the effect of nanoparticles of olive (Olea europaea L.) seeds and its powder on obese hyperlipidemic rats.

Methods: Cellulose of olive seeds were isolated by $15 \% \mathrm{NaoH}$ at $160 \circ \mathrm{C}$ for two hours, according to (Wise et al., 1946).Cellulose Nanocrystals (CNC) were isolated from olive seeds bleached pulp by acid hydrolysis using $65 \%$ sulphuric acid at $45^{\circ} \mathrm{C}$ for 45 minutes as previously described (Hassan et al., 2014). Thirty (30) male albino rats of Sprague Dawley strain divided into six groups. Group(1) fed on the basal diet (negative control), (2)fed on the hyperlipidemic diet (HD) (positive control), (3) fed on $H D+2 \%$ nanoparticles from olive seeds (NOS), (4) fed on HD +4\% NOS, (5) fed on HD +5\% olive seeds powder (OSP), (6) fed on HD $+10 \%$ OSP.
\end{abstract}

Total Phenolic Compounds, Concentration Phenolic Compounds, (SEM) examination, food intake, body weight gain ratio, lipids profile (Total lipids TL, Triglycerides TG, Total cholesterol TC, LDL, HDL \& VLDL), liver functions (AST, \& ALT), Total protein, albiumine, were determined.

Results: The results observed that, the body weight gain ratio $(B W G \%)$, had significantly decrease $(P \leq 0.05)$ in all groups G3: G6 which fed on hyperlipidemic diet supplemented by different levels of NOS or OSP, with mean values of $(-28.85 \pm 2.51 \mathrm{~g},-41.26 \pm 5.51 \mathrm{~g},-12.57 \pm 3.30 \mathrm{~g}$ and $-20.31 \pm 5.39 \mathrm{~g}$, respectively) when compared with the positive control group which fed on hyperlipidemic diet without supplementation $(13.73 \pm 1.91 \mathrm{~g})$. Moreover, rats treatment with nanocellulose from olive seeds (NOS 2\%\& 4\%) had significantly decrease in lipids profile levels (TL, TG, TC, LDL \& VLDL), Liver function when compared with the positive control rats. Also, The lowest value in total cholesterol was recorded with group administrated with nanocellulose from olive seeds (NOS $2 \% \& 4 \%) 73.15^{d} \pm 4.06 \& 73.42^{d} \pm 5.26$ respectively when compared with negative and positive control groups with a mean value of $64.99^{e} \pm 2.90$ and $178.38^{a} \pm 5.69$ respectively. In addition, The lowest value in triglycerides was recorded with group administrated with nanocellulose from olive seeds (NGS 4\%) $88.82^{e}$ \pm 3.91 compared with negative and positive control groups with a mean value of $87.2^{d} \pm 4.02$ and $345.32^{a} \pm 4.21$ respectively. In addition, it revealed that rats were fed on hyperlipidemic diet supplemented with olive seeds powder OSP by different levels $5 \%$ \& $10 \%$ and nanoparticles of olive seeds NOS2\% had significant decrease in the serum AST and ALT when compared with the positive control group except in group (4) which rats fed on hypercholesterolemic diet supplemented with NGS 4\%. Also, the lowest reduction value of AST were found in group (6) when rats fed on hypercholesterolemic diet supplemented with GSP $10 \%$ and ALT were found in group (5)when rats fed on hypercholesterolemic diet supplemented with GSP $5 \% \quad 120.72^{c} \pm 10.64$ \& $57.72^{c}$ $\pm 4.41 U / L$ respectively.

Conclusions: It can be concluded that nanoparticles isolated from olive seeds had a significant positive effects against obesity and Hyperlipidemic than the effects of olive seeds Powder. Hence, the study may be repeated on patients with hyperlipidemia for possible beneficial effect on humans.

Keywords: Hyperlipidemia, Olive seeds, Nanocellulose, Obesity.

\section{INTRODUCTION}

Obesity is one of the main public health problems in developed countries. It is considered to be a risk factor associated with the genesis or development of major chronic diseases, including cardiovascular 
disease, diabetes, and cancer. Dietary supplements containing polyphenol compounds are associated with a reduction of diet-induced obesity. Recent studies indicate that these anti-obesity effects come about through the genes involved in adipogenesis, lipolysis and the oxidation of fatty acids. Due to the powerful antioxidant activity and anti-inflammatory properties of polyphenols derived from the olive, they are the object of numerous studies. Likewise, very recently olives, and the fractions deriving from olive production, have been linked to their effects on obesity-related mechanisms (Hao et al., 2010; Jacomelli et al., 2010).

The olive tree belongs to the genus Olea of the Oleaceae family with 25 genera and about 600 species (Jensen et al., 2002). Members of the Oleaceae family are characterized by the presence of secoiridoids. These compounds have elenolic acid or its derivatives in their structures.Derivatives of elenolic acid include oleosides. Oleosides are not necessarily phenolic compounds but may include a phenolic moiety as a result of esterification (Ryan et al., 2002).

Olives contain high concentrations of phenolic compounds ranging between 1-3\% of the fresh pulp weight. The main classes of phenolic compounds present in olives are phenolic acids, phenolic alcohols, flavonoids and secoiridoids. Hydroxytyrosol and tyrosol are the most abundant phenolic alcohols in olives. The flavonoids include flavonol glycosides such as luteolin-7-glucoside and rutin as well as anthocyanins. Verbascoside, a hydroxycinnamic acid derivative, is also found in these samples. While phenolic acids, phenolic alcohols and flavonoids occur in many fruits and vegetables belonging to various botanical families, secoiridoids are present exclusively in plants belonging to the Oleaceae family which includes Olea europaea L. (Robards et al., 1999; Servili \&Montedoro, 2002; Servili et al., 2004; De la Torre-Carbot et al., 2005). These main phenolic components are hydroxytyrosol, tyrosol, and oleuropein, which occur in highest amounts in virgin olive oil and have antioxidant properties.

Olive oil has shown activity in against cancer, mainly in colon and breast cancer prevention, while individual component of olive oil, oleic acid and squalene has also been identified as anticancer agent. The olive oil has effects on coronary heart disease, due to its ability to reduce blood pressure and lowdensity lipoprotein level.Some components (such as hydroxytyrosol, tyrosol, and oleuropein) of olive oil exhibited antimicrobial activity against pathogenic microorganism in intestinal and respiratory infections. The oleic acid, polyphenolics, squqlenes are dependable for a number of biological activities as well as whole olive plant also gives health benefits (Mohammad, 2013).

The olive fruits contain a wide variety of phenolic compounds (Brenes et al., 1999; Mateos et al., 2001; Ryan et al., 2002; Bianchi, 2003; Owen et al., 2003). They are potent antioxidants and play an important role in the chemical, organoleptic and nutritional properties of the virgin olive oil and the table olives. The positive effect of olives and olive-derived products consumption on human health, well documented by a large number of epidemiological studies (Owen et al., 2000; Pérez-Jiménez, et al., 2005), may be explained in part by the antioxidant effect of these phenolic compounds. As natural dietary antioxidants they may protect the organism against oxidative damage caused by oxidant agents (active oxygen, free radical, etc) that are involved in the etiology of chronic diseases such as cancer and atherosclerosis (Aruoma, 2003; Visioli et al., 2005).

The report of the First International Conference on Olive Oil and Health, held in Jaen, Spain, in 2004 highlighted the benefits of olive oil consumption on the lipid profile. The plasma cholesterolpredictive equations, developed in the mid-1960s (Keys, 1965; Hegsted et al., 1965) from data of controlled diet studies, showed that consumption of MUFA did not affect total cholesterol levels, but the consumption of SFA raised them. Consumption of PUFA and MUFA lowered total cholesterol.

Recent studies have confirmed these findings, although there were some data that in MUFA consumption the low-density lipoprotein (LDL) cholesterol-lowering effect was less, whereas the high-density lipoprotein cholesterol (HDL) was higher than those observed for PUFA.The results of a meta-analysis of 14 studies showed that replacement of SFA by oils enriched in MUFA versus PUFA had similar effects on total, LDL, and HDL cholesterol (Howard et al.,1995).The PUFA-enriched oil had a slight triglyceride lowering effect, and there was an increase in HDL cholesterol after MUFA consumption in some studies. Recent data confirm the HDL cholesterol-increasing effect of olive oil consumption both within and out of the frame of the Mediterranean diet. Both a high-fat diet $(40 \%$ of energy) rich in MUFA and low in SFA and a low-fat carbohydrate-rich diet had similar cholesterol- 
The Impact of Olive Seeds (Olea europaea L.) Powder (OSP) and its Nanoparticles (NOS) on Obese Hyperlipidemic Rats.

lowering effects. However, a high MUFA diet did not lower HDL cholesterol or increase triglycerides as did the carbohydrate-rich diet (Mensink \& Katan, 1992).

Veciana-Galindo et al., 2015 their results showed that, the addition of olive seed extract at $50 \mathrm{mg} / \mathrm{l}$ of polyphenols was observed to be extremely effective in inhibiting the formation of fatty substances during adipogenesis.

Few studies have focused on the phenolic composition of olive seeds. However some phenolic compounds have been identified in olive seeds, such as salidroside, nüzhenide, hydroxytyrosol, nüzhenide 11-methyl oleoside, oleuropein, tyrosol, and demethyloleuropein (Maestro-Durán et al., 1994).Nüzhenide (nüzhenzi in chinese medicine), was for the first time fully characterized by NMR spectroscopy in 1999 (Servili et al., 1999).

The study was carried out to investigate the effect of nanoparticles of olive (Olea europaea L.) seeds and its powder on obese hyperlipidemic rats.

\section{Materials ANd Methods}

\section{2-1. Animals}

Male albino rats (n=30rats) weighing $(60.00 \pm 5.00 \mathrm{~g})$ of Sprsgue Dawley strain were obtained from the Laboratory Animals Colony, Ministry of Health and Population, Helwan, Egypt.

\section{2-2. Materials}

\section{2-2-1. Chemicals}

Casein was obtained from Morgan Company of chemical and nutritional products, Cairo, Egypt.Vitamins mix, minerals mix,cellulose and choline were obtained from El-gomhoria Company (Co.) for pharmaceutical and chemicals, Cairo, Egypt.

\section{2-2-2. Kits}

Kits used to determine serum total lipid ,total cholesterol, triglycerides, HDL-c,LDL-c,VLDL-c, AST ,ALT, total protein ,Albumin ,Urea ,Uric and Creatinine were being obtained from Gamma Trade Co. for pharmaceutical and chemicals, Dokki, Egypt.

\section{2-3. Preparation of Olive Seed Powder}

Olive seeds were collected from local market, Olive seeds washed and dried for two days then grinded by using (dry blander, Panasonic) and the powder formed was sieved until certain sizes were achieved.

\section{2-4. Determination of Total Phenolic and Flavonoids Compounds}

A sample from Olive seeds powder were taken to determine Phenolic compounds and Flavonoids according to(Goupy et al., 1999; Mattila et al., 2000).

\section{2-5. Extraction of Cellulose from Olive seeds}

Olive seeds were washed with water, and pulped using $15 \% \mathrm{NaOH}$ at $160 \circ \mathrm{C}$ for two hours. The produced pulp was further bleached using sodium chlorite/acetic acid mixture according to previously published method (Wise et al., 1946).

\section{2-5-1. Preparation of Nanocellulose}

Cellulose Nanocrystals (CNC) were isolated from Olive seeds bleached pulp by acid hydrolysis using $65 \%$ sulphuric acid at $45^{\circ} \mathrm{C}$ for 45 minutes as previously described (Hassan et al., 2014). The hydrolyzed cellulose sample was washed five times by centrifugation $\left(10.000 \mathrm{rpm}, 10 \mathrm{~min}\right.$, and $\left.10^{\circ} \mathrm{C}\right)$ to remove excess sulphuric acid .The suspension was then dialyzed against distilled water until a constant $\mathrm{PH}$ was achieved .The resultant cellulose nanocrystal suspension was stored at $4 \pm^{\circ} \mathrm{C}$ until further used.

\section{2-6. Scanning Electronic Microscopy (SEM) examination}

Transmission electron microscopy (TEM) of the prepared cellulose nanocrystals was carried out using a JEOL 1230 transmission electron microscope (Japan) with acceleration voltage $100 \mathrm{kV}$. 


\section{2-7. Preparation of the basal diet and high fat diet}

Basal diet and high fat diet for rats was prepared according to AIN 93M(Reeves et al., 1993).

Hypercholesterolemic diet (high fat diet) : groups were fed a modified AIN-93G diet containing 5 $\mathrm{g} / 100 \mathrm{~g}$ lard, $1 \mathrm{~g} / 100 \mathrm{~g}$ cholesterol, and $0.25 \mathrm{~g} / 100 \mathrm{~g}$ cholate according to ( $\boldsymbol{G} \mathbf{X} \boldsymbol{e}$ et al., 2007).

\section{2-8. Experimental Animals and Design}

The present experiment was done in the animal house, Faculty of Home Economics, Helwan University, Cairo, Egypt. It was carried out on $\left(\mathrm{n}_{\sharp} 30\right)$ male albino rats of Sprague Dawley strain $(60.00 \pm 5.00 \mathrm{~g}$ b.wt.). Animals were housed in a normal healthy condition and allowed water was available. High fat diet was provided for four (4) week before starting the experiment (period 1). After this period (four week) experimental period 2 rats were divided into two main groups. Then the rats will be divided into six (6) groups. Each group containing 5 rats. Group (1): Fed on the basal diet (the negative control). Group (2): Fed on the hyperlipidemic diet without supplementation (the positive control).Group (3): Fed on the hyperlipidemic diet $+2 \%$ of nanoparticles from Olive seeds. Group (4): Fed on the hyperlipidemic diet (HD) $+4 \%$ of nanoparticles from Olive seeds (NOS). Group (5): Fed on the hyperlipidemic diet (HD) $+5 \%$ from Olive seeds powder (OSP). Group (6): Fed on the hyperlipidemic diet (HD) $+10 \%$ from Olive seeds powder (OSP). At the end of the experimental period (four (4) weeks), rats will be fasted overnight before sacrifice and the blood will be collected and centrifuged for collection the serum.

\section{2-9. Biological Determination}

Biological determination were carried out by determination of feed intake (FI) which was calculated every day throughout the experimental period (4 weeks). Over all Body weight gain (BWG) and organs / body weight ratio were determined according to (Chapman et al., 1959).

\section{2-10. Collection of Serum and Tissue Samples}

At the end of the experimental period (4 weeks), rats were sacrificed. Blood samples were immediately collected in clean and dry tubes from the portal vein and left to clot at room temperature. Blood samples were centrifuged at $3000 \mathrm{rpm}$ for 15 minutes to separate serum. Serum was carefully separated into dry clean tubes and allowed to be frozen at $-10^{\circ} \mathrm{c}$ until the determination of the tested parameters.

\section{2-11. Biochemical Analysis}

2-11-1. Determination of Triglycerides Concentration: Serum triglycerides was determined according to(Fossati \& Prancipel, 1982).

2-11.2.Determination of Total Cholesterol Concentration: Serum cholesterol was determined according to (Allain et al., 1974).

2-11-3. Determination of HDL-Cholesterol Concentration: Serum HDL-Cholesterol was determined according to (Burstein et al., 1970).

2-11-4. Determination of LDL-Cholesterol and VLDL-Cholesterol Concentration: Serum LDLCholesterol and VLDL-Cholesterol were determined according to(Friedewald et al., 1972).

2-11-5. Determination of Serum Alanine amino transferase (ALT): The enzyme alanine amino transeferase (ALT) This enzyme was determined in serum according to Sherwin (1984).

2-11-6. Determination of Serum Aspartate Amino Transferase (AST): The enzyme aspartate amino transeferase (AST) was determined according to Young (1990).

\begin{tabular}{|c|c|}
\hline Phenolic Compounds & Test Results $(\mu \mathrm{g} / 100 \mathrm{~g})$ \\
\hline Gallic Acid & 36.4 \\
\hline Pyrogallol & 925.17 \\
\hline 3-OH-Tyrosol & 27549.47 \\
\hline 4-Amino-benzoic & 89.06 \\
\hline Protocatechuic & 859.05 \\
\hline
\end{tabular}


The Impact of Olive Seeds (Olea europaea L.) Powder (OSP) and its Nanoparticles (NOS) on Obese Hyperlipidemic Rats.

\begin{tabular}{|l|}
\hline Chlorogenic \\
\hline Catechol \\
\hline EpiCatechein \\
\hline Catechein \\
\hline Caffeine \\
\hline P-OH- benzoic \\
\hline Caffeic Acid \\
\hline Vanillic Acid \\
\hline Ferulic \\
\hline Iso- ferulic \\
\hline e-vanillic \\
\hline Reversetrol \\
\hline Oleuropin \\
\hline Ellagic \\
\hline Alpha - coumaric \\
\hline Benzoic \\
\hline 3.4.5- methoxy-cinnamic \\
\hline Coumarin \\
\hline Salycilic \\
\hline p-coumaric \\
\hline Cinnamic \\
\hline
\end{tabular}

\begin{tabular}{|c|c|}
\hline 707.41 \\
\hline 742.96 \\
\hline----- \\
\hline 285.68 \\
\hline 2083.41 \\
\hline 1059.89 \\
\hline 294.27 \\
\hline 762.3 \\
\hline 492.07 \\
\hline 21621.26 \\
\hline 575.05 \\
\hline 6368.86 \\
\hline 696.92 \\
\hline 1240.34 \\
\hline 5823.42 \\
\hline 999.51 \\
\hline 1883.8 \\
\hline 2981.3 \\
\hline 205.04 \\
\hline 433.17 \\
\hline
\end{tabular}

2-11-7. Determination of Total Lipid: Determination of total lipid was according to Folch et al., 1957.

2-11-8. Determination of Serum Albumin Concentration: Serum albumin level was determined as described by Young (1990) using spectrophotometer at $630 \mathrm{~nm}$.

2-11-9. Determination of Total Protein Concentration: Protein concentrations were determined by the method of Lowry et al. (1951) using bovine serum albumin as the standard.

\section{2-12. Statistical Analysis of Data}

Results of biochemical analysis and biological evaluation of each group were Statistical analyzed(Mean, Standard deviation and one way ANOVA teat)using SAS package and compared with each other using suitable test [Least Significant difference (L.S.D.)and correlation coefficient] (Armitage \& Berry,1987).

\section{RESULTS AND DISCUSSION}

\section{3-1. Phenolic Compounds}

It is obvious that the total phenolic content measured by the Folin-Ciocalteu procedure does not give a full picture of the quality or quantity of the phenolic constituents in the extracts as reported in literature (Katsube et al., 2004; Wu et al., 2004).PLC is the preferred technique for both separation and quantification of phenolic compounds (Naczk \& Shahidi, 2004). Various factors affect HPLC analysis of phenolics, including sample purification, mobile phase, column types and detectors (Stalikas, 2007). In general, purified phenolics are applied to an HPLC instrument utilizing a reversed phase C18column (RP-C18), photo diode array detector (PDA) and polar acidified organic solvents(Ignat et al., 2011). From the data in Table (1) it could be observed that the total amount of phenolic compounds varied for olive seeds powder samples (36.4 mg of gallic acid, $27549.47 \mu \mathrm{g}$ of hydroxyl tyrosol, $1059.89 \mu \mathrm{g}$ of caffeic acid, $294.27 \mu \mathrm{g}$ of Vanillic acid). It could be concluded that olive seeds are not waste worthless, they should be considered as an interesting source of potent antioxidants such phenolic compounds. Result showed that tyrosol is the major phenolic present in olive seeds our study were in the same line with those reported by

Table (2): The Concentration Flavonoids Compounds $(\mu \mathrm{g} / 100 \mathrm{~g})$ in Investigated Samples of Olive Seeds Powder (OSP) by HPLC:

\begin{tabular}{|l|}
\hline Flavonoids \\
\hline Naringin \\
\hline Rutin \\
\hline Hisperdin \\
\hline
\end{tabular}

\begin{tabular}{|c|}
\hline Test Results Of Flavonoids $(\boldsymbol{\mu g} / \mathbf{1 0 0 g})$ \\
\hline 2880.94 \\
227.39 \\
2669.76 \\
\hline
\end{tabular}


Mohamed S.M.E. Abdelbaky et al.

\begin{tabular}{l|c}
\hline Rosmarinic & 172.96 \\
\hline \hline Quercetrin & 398.97 \\
\hline Quercetin & 122.99 \\
\hline Narengenin & 18.04 \\
\hline Kampferol & 51.03 \\
\hline Hispertin & 1112.34 \\
\hline Apegenin & 33.91 \\
\hline 7-OH flavone & 12.28 \\
\hline
\end{tabular}

(Fabiani et al., 2002; Visioli et al., 2004 and Charoenprasert \& Mitchell 2012), who found that hydroxytyrosol is one of major phenolic compounds present in olive seeds and it has been revealed to be the most interesting, because of its remarkable pharmacological and antioxidant activity.

\section{3-2. Flavonoids Compounds}

Flavonoids have negligible systemic antioxidant activity. The concentration of flavonoids compounds in the samples of red grape seeds powder was recorded in Table (2).Data showed that HPLC analysis of flavonoids compounds concentration (ug/100gm) in olive seeds methanolic extract. It had the major compound is (Naringin $2880.94 \mu \mathrm{g} / 100 \mathrm{~g}$ ), then (Hisperdin 2669.76 $\mu \mathrm{g} / 100 \mathrm{~g}$ ). The results showed that olive seeds was considered as an interesting source of flavonoids, and the results are agreement with Charoenprasert \& Mitchell 2012.

\section{3-3.Cellulose Nanocrystals Obtained From Olive Seeds}

Figure (1) shows TEM images of cellulose nanocrystals isolated from olive seeds. The image shows olive stones cellulose nanocrystals with length from 127-145 nm and width of about $3 \mathrm{~nm}$ as recorded in Figure (1\&2). Cellulose nanocrystals were oxidized by using TEMPO-mediated chlorite oxidation; the reaction selectively converts the primary hydroxyl groups at the surfaces of cellulose nanocrystals to carboxylic acids.
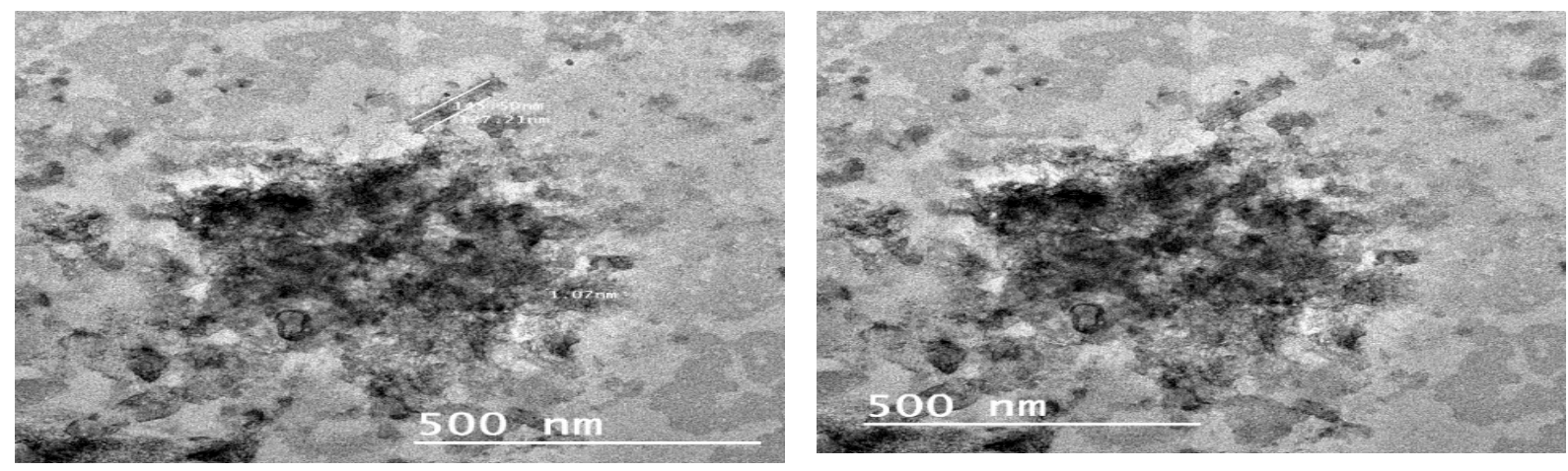

Figure (1). TEM images of cellulose nanocrystals obtained from olive seeds.

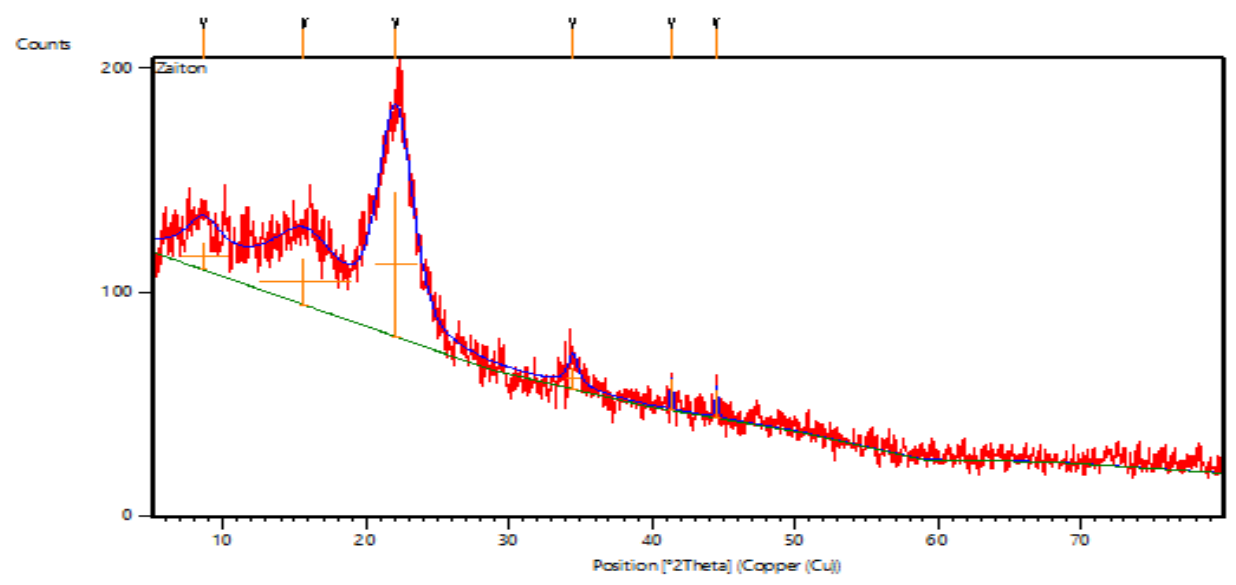

Figure (2). Crystallite Size Determination of Cellulose Nanocrystals Obtained from Olive Seeds. 
The Impact of Olive Seeds (Olea europaea L.) Powder (OSP) and its Nanoparticles (NOS) on Obese Hyperlipidemic Rats.

$\underline{\text { Peak List }}$

\begin{tabular}{|c|c|c|c|c|}
\hline Pos. $\left[{ }^{\circ} 2 \mathrm{Th}.\right]$ & Height & FWHMLeft $\left[{ }^{\circ} 2 \mathrm{Th}.\right]$ & $d$-spacing $[\AA]$ & Rel. Int. [\%] \\
\hline $9(2)$ & $12(5)$ & $3(2)$ & 10.26264 & 18.89 \\
\hline $16(3)$ & $21(2)$ & $6(3)$ & 5.65522 & 32.6 \\
\hline $22.1(2)$ & $65(5)$ & $3(1)$ & 4.02419 & 100.00 \\
\hline $34(3)$ & $10(3)$ & $1(2)$ & 2.60192 & 15 \\
\hline $41.35(2)$ & $14(12)$ & $0.1(2)$ & 2.18177 & 22.2 \\
\hline $44(1)$ & $13(166)$ & $0(1)$ & 2.03519 & 19.4 \\
\hline
\end{tabular}

Table (3): Effect of basal diet and hyperlipidemic diet (HD) on obesity in experimental Rats (Mean \pm SD).

\begin{tabular}{|l|c|c|}
\hline \multicolumn{1}{|c|}{ Proups } & Feed Intake (g/day) (1) & BWG \%(1) \\
\cline { 2 - 3 } & Mean \pm SD & Mean \pm SD \\
\hline G 1:Control negative (C-) & $11.00^{\mathrm{f}} \pm 0.00$ & $46.53^{\mathrm{c}} \pm 5.70$ \\
\hline G2:Control positive (C+) & $13.00^{\mathrm{e}} \pm 0.00$ & $200.71^{\mathrm{ab}} \pm 16.40$ \\
\hline G3: Fed on HD only & $13.80^{\mathrm{c}} \pm 0.00$ & $178.78^{\mathrm{b}} \pm 11.94$ \\
\hline G4: Fed on HD only & $14.20^{\mathrm{b}} \pm 0.00$ & $229.49^{\mathrm{a}} \pm 28.44$ \\
\hline G5: Fed on HD only & $13.40^{\mathrm{d}} \pm 0.00$ & $211^{\mathrm{a}} \pm 6^{\mathrm{ab}} \pm 38.08$ \\
\hline G6: Fed on HD only & $14.30^{\mathrm{a}} \pm 0.00$ & $209.60^{\mathrm{ab}} \pm 23.12$ \\
\hline F. Value & $3.139 \mathrm{E}+31$ & 28.79 \\
\hline Sig. & 0.000 & 0.000 \\
\hline \multicolumn{2}{|c|}{ Values are expressed as mean \pm SD .Significance at the P $\leq 0.05$ level. } \\
\hline
\end{tabular}

\section{3-4. Food Intake (1) and Body Weight Gain Ratio (BWG\%) (1) To Induce Obesity In The Experimental Period (1)}

The bioactive effect of nanoparticles olive seeds and its powder on body weight gain on experimental rats was recorded in Table (3). Results showed non-significant increase of feed intake in rats fen on hyperlipidemic diet only (G2, G3, G4, G5 \&G6) compared with the negative control group which fed on basal diet.

Table (4): Effect of Nanoparticles of Olive Seeds (N.O.S) and its powder (O.S.P) on Feed Intake FI (2) and Body Weight Gain ratio (2) (B.W.G \%) in Obese Hyperlipidemic Rats (Mean \pm SD).

\begin{tabular}{|l|c|c|}
\hline \multicolumn{1}{|c|}{ Parameters } & $\begin{array}{c}\text { Feed Intake } \\
\text { (g/day) (2) }\end{array}$ & BWG(\%)(2) \\
\cline { 2 - 3 } & Mean \pm SD & Mean \pm SD \\
\hline G1:Control negative (C-) & $9.90^{\mathrm{e}} \pm 0.00$ & $34.69^{\mathrm{b}} \pm 3.01$ \\
\hline G2:Control positive (C+) & $16.00^{\mathrm{a}} \pm 0.00$ & $13.73^{\mathrm{e}} \pm 1.91$ \\
\hline G3:N.O.S 2\% & $14.30^{\mathrm{b}} \pm 0.00$ & $-28.85^{\mathrm{c}} \pm 2.51$ \\
\hline G4:N.O.S 4\% & $11.80^{\mathrm{d}} \pm 0.00$ & $-41.26^{\mathrm{a}} \pm 5.51$ \\
\hline G5:O.S.P. 5\% & $13.90^{\mathrm{c}} \pm 0.00$ & $-12.57^{\mathrm{e}} \pm 3.30$ \\
\hline G6:O.S.P. 10\% & $9.90^{\mathrm{e}} \pm 0.00$ & $-20.31^{\mathrm{d}} \pm 5.39$ \\
\hline F. Value & $1.561 \mathrm{E}+32$ & 36.22 \\
\hline Sig. & 0.000 & 0.000 \\
\hline
\end{tabular}

Regarding body weight gain ratio (BWG\%), for all groups (G2:G6) fed on hyperlipidemic diet HD had highly significant increase when compared with the negative control group which fed on basal diet . The highest value in BWG\% were found in group 4 which fed on hyperlipidemic diet $229.49^{\mathrm{a}}$ \pm 28.44 .

\section{3-5.Food Intake and Body Weight Gain Ratio (BWG\%) In The Experimental Period (2)}

The bioactive effect of nanoparticles of olive seeds and its powder on feed intake and body weight gain in obese hyperlipidemic rats was recorded in Table (4). Results showed that all groups rats fed on experimental diet(HD) with or without supplementation by different levels of NOS or OSP had significant increase in feed intake compared to rats fed on basal diet (control negative), except group(6) which fed on hypercholesterolemic diet HD supplemented by $10 \%$ olive seeds powder (OSP). In addition, all groups G3: G6 which fed on hyperlipidemic diet supplemented by different 
levels of NOS or OSP showed significant reduced feed intake compared to positive control rats which fed on hyperlipidemic diet without supplementation.

In addition, it could be observed that, the body weight gain ratio (BWG\%), had significantly decrease $(\mathrm{P} \leq 0.05)$ in rats fed on hyperlipidemic diet HD without supplementation (control positive) when compared to rats fed on basal diet (control negative ) with mean value $(13.73 \pm 1.91$ and $34.69 \pm 3.01 \mathrm{~g}$, respectively). Moreover, it could be observed that, the body weight gain ratio (BWG\%), had significantly decrease $(\mathrm{P} \leq 0.05)$ in all groups $\mathrm{G} 3$ : G6 which fed on hyperlipidemic diet supplemented by different levels of NOS or OSP, with mean values of $(-28.85 \pm 2.51 \mathrm{~g},-41.26 \pm 5.51 \mathrm{~g},-12.57 \pm 3.30$ $\mathrm{g}$ and $-20.31 \pm 5.39 \mathrm{~g}$, respectively) when compared with the positive control group which fed on hyperlipidemic diet without supplementation $(13.73 \pm 1.91 \mathrm{~g})$. The results are agreement with $\boldsymbol{G U I} \mathbf{Y u}$, et al., (2014) who studied hypolipidemic Effects of Different Particle Sizes of Cellulose from Sweet Potato Residue in Ovariectomized Hyperlipidemia Rats. Fortymature female Wistar rats were randomly divided into five groups. One group was sham-ovariectomized (OVX) as shamoperation group. The other four groups were double ovariectomized and one week later assigned as blank group, ordinarycellulose group, ultrafine cellulose group and nanocellulose group. Results reported that as the cellulose particle size decreased, the body weight gain and food intake of cellulose-fed OVX rats decreased. all three cellulose particles had a strong adsorption capacity towards fats, cholesterol and sodiumcholate and smaller particles size resulted in an increase in the adsorption capacity of fats and sodium cholate. Plasma totalcholesterol (TC), triglyceride (TG), and low density lipoproteincholesterol (LDL-C), arteriosclerosis index (AI) and livertotal fat and TG and of OVX rats exhibited a decrease. There were positive correlations between decreasing trends of plasmaTC, TG and LDL-C in OVX rats and cellulose particle size. It concluded that the adsorption capacity of cellulose towards fatand bile salts can be increased by reducing its particle size, consequently improving the hypolipidemic effect in OVX rats.

\section{3-6.Organs (Liver, Kidney, Heart and Spleen) / body Weight ratio}

Data in Table (5) Results indicated insignificant difference between all groups on liver relative weight. However, rats (positive control) were caused decreased liver relative weight but was not statistically significant with a mean value $2.70 \pm 0.34 \%$ compared with rats fed on basal diet (negative control group) with a mean value of $3.33 \pm 0.69 \%$.

\begin{tabular}{|c|c|c|c|c|}
\hline \multicolumn{5}{|c|}{$\begin{array}{l}\text { Table (5): Effect of Nanoparticles of Olive Seeds and its Powder on Organs / Body Weight (B.W) } \\
\text { Ratio \% in Obese Hyperlipidemic Rats }(\text { mean } \pm \text { SD). }\end{array}$} \\
\hline \multirow[t]{2}{*}{ Parameters } & $\begin{array}{l}\text { Liver / body } \\
\text { weight } \%\end{array}$ & $\begin{array}{l}\text { Kidney / body } \\
\text { weight } \%\end{array}$ & $\begin{array}{l}\text { Heart / body } \\
\text { weight \% }\end{array}$ & $\begin{array}{l}\text { Spleen / body } \\
\text { weight } \%\end{array}$ \\
\hline & Mean \pm SD & Mean \pm SD & Mean \pm SD & Mean \pm SD \\
\hline G1:Control negative (C-) & $3.33^{b} \pm 0.69$ & $0.85^{b} \pm 0.16$ & $0.36^{\mathrm{bc}} \pm 0.02$ & $0.34^{\mathrm{a}} \pm 0.13$ \\
\hline G2:Control positive $(\mathrm{C}+)$ & $2.70^{\mathbf{b}} \pm 0.34$ & $0.69^{\mathrm{b}} \pm 0.11$ & $0.25^{\mathrm{e}} \pm 0.03$ & $0.22^{b} \pm 0.35$ \\
\hline G3:N.O.S 2\% & $4.03^{\mathrm{a}} \pm 0.43$ & $1.02^{\mathrm{a}} \pm 0.10$ & $0.38^{\mathrm{ab}} \pm 0.02$ & $0.27^{\mathbf{a b}} \pm 0.02$ \\
\hline G4:N.O.S 4\% & $3.26^{\mathrm{b}} \pm 0.33$ & $1.05^{\mathrm{a}} \pm 0.12$ & $0.41^{\mathrm{a}} \pm 0.05$ & $0.35^{\mathrm{a}} \pm 0.08$ \\
\hline G5:O.S.P. 5\% & $2.72^{\mathrm{b}} \pm 0.30$ & $0.74^{b} \pm 0.04$ & $0.32^{\mathrm{cd}} \pm 0.02$ & $0.21^{\mathbf{b}} \pm 0.01$ \\
\hline G6:O.S.P. $10 \%$ & $3.01^{b} \pm 0.20$ & $0.77^{\mathbf{b}} \pm 0.02$ & $0.30^{\mathrm{de}} \pm 0.005$ & $0.23^{\mathbf{b}} \pm 0.02$ \\
\hline F. Value & 5.726 & 7.782 & 11.77 & 3.602 \\
\hline Sig. & 0.002 & 0.000 & 0.000 & 0.020 \\
\hline
\end{tabular}

However, rats fed on experimental HD diet containing $2 \%$ N.O.S showed significant increase in liver relative weight with a mean value of $4.03 \pm 0.43 \%$ compared to the positive control rats $(2.70 \pm 0.34 \%)$.

Moreover, it could be observed that significant and non significant increase in kidney / body weight ratio were found for all groups fed on experimental HD diet supplemented with NOS or OSP by different levels when compared with control positive group fed on hyperlipidemic diet HD without supplementation. Whereas, rats fed on experimental HD diet containing $2 \%$ N.O.S and $4 \%$ N.O.S showed significant increase in kidney / body weight ratio, with mean value of $(1.02 \pm 0.10 \%$ and 1.05 $\pm 0.12 \%$, respectively ) compared to the positive control group with a mean value $\left(0.69^{\mathrm{b}} \pm 0.11 \%\right)$.

In addition, it could be observed that significant and non significant difference in heart and spleen / body weight ratio for all groups fed on fed on experimental HD diet supplemented with NOS or OSP 
The Impact of Olive Seeds (Olea europaea L.) Powder (OSP) and its Nanoparticles (NOS) on Obese Hyperlipidemic Rats.

by different levels when compared with control positive group fed on hyperlipidemic diet HD without supplementation.

\section{3-7. Blood Lipids Profile}

Table (6): Effect of Nanoparticles of Olive Seeds and its powder on Total Lipids, Total Cholesterol and Triglycerides on Obese Hyperlipidemic Rats (Mean \pm SD).

\begin{tabular}{|l|c|c|c|}
\hline \multicolumn{1}{|c|}{ Parameters } & \multicolumn{1}{|c|}{$\begin{array}{c}\text { T. lipids } \\
\text { Groups }\end{array}$} & $\begin{array}{c}\text { T. Cholesterol } \\
(\mathbf{m g} / \mathbf{d l})\end{array}$ & $\begin{array}{c}\text { Triglycerides } \\
\text { (mg/dl) }\end{array}$ \\
\cline { 2 - 4 } & Mean \pm SD & Mean \pm SD & Mean \pm SD \\
\hline G1:Control negative (C-) & $257.07^{\mathrm{c}} \pm 6.74$ & $64.99^{\mathrm{e}} \pm 2.90$ & $87.2^{\mathrm{e}} \pm 4.02$ \\
\hline G2:Control positive (C+) & $661.72^{\mathrm{a}} \pm 6.85$ & $178.38^{\mathrm{a}} \pm 5.69$ & $345.32^{\mathrm{a}} \pm 4.21$ \\
\hline G3:N.O.S 2\% & $219.09^{\mathrm{de}} \pm 8.17$ & $73.15^{\mathrm{d}} \pm 4.06$ & $115.42^{\mathrm{c}} \pm 7.33$ \\
\hline G4:N.O.S 4\% & $211.26^{\mathrm{e}} \pm 5.40$ & $73.42^{\mathrm{d}} \pm 5.26$ & $88.82^{\mathrm{e}} \pm 3.91$ \\
\hline G5:O.S.P. 5\% & $274.48^{\mathrm{b}} \pm 3.28$ & $97.35^{\mathrm{c}} \pm 4.96$ & $140.60^{\mathrm{b}} \pm 6.76$ \\
\hline G6:O.S.P. 10\% & $228.43^{\mathrm{d}} \pm 5.73$ & $106.70^{\mathrm{b}} \pm 2.97$ & $104.02^{\mathrm{d}} \pm 7.17$ \\
\hline F. Value & 3085.96 & 35786 & 1178.36 \\
\hline Sig. & 0.000 & 0.000 & 0.000 \\
\hline Values are expressed as mean \pm SD .Significance at the P $\leq 0.05$ level. & \\
\hline
\end{tabular}

The bioactive effect of olive seeds powder and nanoparticles of olive seeds on serum total lipids, total cholesterol and triglycerides in Obese Hyperlipidemic Rats were recorded in Table (6).

The results showed significant decreased in serum total lipids for all groups fed on high fat diet fed supplemented with olive seeds powder OSP and nanocellulose NOS by different levels . It showed that treatment with nanocellulose from olive seeds (NOS 4\%) had the lowest significant decrease in total lipids with a mean value of $211.26^{\mathrm{e}} \pm 5.40$ compared with (positive and negative control groups) with a mean value of $661.72^{\mathrm{a}} \pm 6.85$ and $257.07^{\mathrm{c}} \pm 6.74$ respectively .

Moreover, the same results indicated that significant decreased in total cholesterol and triglycerides were recorded for rats fed on basal diet (control negative group) and rats fed on hypercholesterolemic diet supplemented with nanocellulose from olive seeds (NOS $2 \%$ \& 4\%) or olive seeds powder (OSP $5 \%$ \& 10\%)when compared with rats fed on hypercholesterolemic diet without supplementation (control positive group). Also, The lowest value in total cholesterol was recorded with group administrated with nanocellulose from olive seeds (NOS $2 \% \& 4 \%$ ) $73.15^{\mathrm{d}} \pm 4.06 \& 73.42^{\mathrm{d}} \pm 5.26$ respectively when compared with negative and positive control groups with a mean value of $64.99^{\mathbf{e}}$ \pm 2.90 and $178.38^{\mathrm{a}} \pm 5.69$ respectively. In addition, The lowest value in triglycerides was recorded with group administrated with nanocellulose from olive seeds (NGS $4 \%$ ) $88.82^{\mathrm{e}} \pm 3.91$ compared with negative and positive control groups with a mean value of $87.2^{\mathrm{d}} \pm 4.02$ and $345.32^{\mathrm{a}} \pm 4.21$ respectively.

Data in table (7) were showed the effect of olive seeds powder (OSP) and nanocellulose from olive seeds (NOS) on (HDL, LDL and VLDL) lipoproteins in obese hypercholesterolemic rats .It could be showed that serum high density lipoprotein (HDL) was significantly increased in rats suffering from hyperlipidemia (positive control group) with a mean value of $\left(41.70^{\mathrm{a}} \pm 2.04 \mathrm{mg} / \mathrm{dl}\right)$ compared with the negative control group with a mean value of $\left(29.70^{\mathrm{b}} \pm 1.80 \mathrm{mg} / \mathrm{dl}\right)$. However, groups administrated olive seeds powder (OSP 5\%\& 10\%) or nanocellulose from grape seeds (NGS 4\%) had significant and non-significant increase in serum high density lipoprotein (HDL) when compared to the positive control groups.

Table (7): Effect of Nanoparticles of Olive Seeds and its powder on Serum High Density Lipoprotein (HDL-C), Serum Low Density Lipoprotein (LDL-C) and Very Low Density Lipoprotein (VLDL-C) in Obese Hyperlipidemic Rats (Mean \pm SD).

\begin{tabular}{|c|c|c|c|}
\hline \multirow[t]{2}{*}{ Parameters } & $\begin{array}{c}\text { HDL } \\
\text { (mg/dl) }\end{array}$ & $\begin{array}{c}\text { LDL } \\
(\mathrm{mg} / \mathrm{dl})\end{array}$ & $\begin{array}{c}\text { VLDL } \\
\text { (mg/dl) }\end{array}$ \\
\hline & Mean \pm SD & Mean \pm SD & Mean \pm SD \\
\hline G1:Control negative (C-) & $29.70^{c} \pm 1.80$ & $17.85^{\mathrm{d}} \pm 1.32$ & $17.44^{\mathrm{e}} \pm 0.80$ \\
\hline G2:Control positive $(\mathrm{C}+)$ & $41.70^{\mathrm{b}} \pm 2.04$ & $67.62^{\mathrm{a}} \pm 4.65$ & $69.06^{\mathrm{a}} \pm 0.84$ \\
\hline G3:N.O.S $2 \%$ & $33.60^{c} \pm 4.59$ & $16.46^{\mathrm{de}} \pm 1.20$ & $23.08^{c} \pm 1.46$ \\
\hline G4:N.O.S 4\% & $42.60^{\mathrm{b}} \pm 5.41$ & $13.06^{\mathrm{e}} \pm 0.79$ & $17.76^{\mathrm{e}} \pm 0.78$ \\
\hline
\end{tabular}


Mohamed S.M.E. Abdelbaky et al.

\begin{tabular}{|l|c|c|c|}
\hline G5:O.S.P. 5\% & $44.10^{\mathrm{ab}} \pm 3.96$ & $25.13^{\mathrm{c}} \pm 2.87$ & $28.12^{\mathrm{b}} \pm 1.35$ \\
\hline G6:O.S.P. 10\% & $49.50^{\mathrm{a}} \pm 6.22$ & $36.39^{\mathrm{b}} \pm 4.79$ & $20.80^{\mathrm{d}} \pm 1.43$ \\
\hline F. Value & 11.26 & 177.21 & 1178.36 \\
\hline Sig. & 0.000 & 0.000 & 0.000 \\
\hline \multicolumn{2}{|l|}{ Values are expressed as mean \pm SD .Significance at the $\mathrm{P} \leq 0.05$ level. } \\
\hline
\end{tabular}

In the same table, results showed that serum low density lipoprotein (LDL) and very low density lipoprotein (VLDL) were increased significantly in rats suffering from hyperlipidemia (positive control group) with a mean value of $\left(67.62^{\mathrm{a}} \pm 4.65 \mathrm{mg} / \mathrm{dl}\right)$ and $\left(69.06^{\mathrm{a}} \pm 0.84 \mathrm{mg} / \mathrm{dl}\right)$ respectively, compared with the negative control group with a mean value of $\left(17.85^{\mathrm{c}} \pm 1.32 \mathrm{mg} / \mathrm{dl}\right)$ and $\left(17.44^{\mathrm{d}}\right.$ $\pm 0.80 \mathrm{mg} / \mathrm{dl}$ ) respectively. While, all groups fed on hypercholesterolemic diet supplemented with olive seeds powder (OSP 5\% \& 10\%) or nanocellulose from grape seeds (NGS $2 \%$ \& 4\%) had significant decrease in serum LDL and VLDL when compared to the positive control rats. The lowest value in serum vLDL was recorded by group (NGS 4\%). The results are agreement with Liu and Li (2016) who reported that the effect of sweet potato residue cellulose on regulating blood glucose was more significant with the decrease of particle size. The content of serum insulin and hepatic glycogen increased significantly in group of nano sweet potato residue cellulose ( $\mathrm{CNC}$ group) ( $\mathrm{p}<0.05)$. Nano sweet potato residue cellulose not only helped to decrease fasting blood glucose, glycosylated serum protein content, serum TC, TG and LDL-L content ( $\mathrm{p}<0.05)$, but also led to a decrease in liver fat concentration, content of TC and TG, which indicated that nano sweet potato residue cellulose had favorable effects on improving pancreatic tissue morphology as well as reducing blood glucose. In addition , Zhong, etal., (2012) Compared the effects of nano-sized sugarcane fiber with cellulose and psyllium on hepatic cellular signaling in mice. It suggested that the modulation of gastrointestinal factors by dietary fibers may play a key role in both enhancing hepatic multiple cellular signaling and reducing lipid accumulation.

\section{3- 8. Liver Functions (AST and ALT)}

Table (8): Effect of Nanoparticles of Olive Seeds and its powder on Serum total Protein, Albumin, AST and ALT Levels on Obese Hyperlipidemic Rats (Mean \pm SD).

\begin{tabular}{|c|c|c|c|c|}
\hline Parameters & $\begin{array}{c}\text { Total protein } \\
\text { g/L }\end{array}$ & $\begin{array}{c}\text { Albumin } \\
\text { g/L }\end{array}$ & $\begin{array}{l}\text { Serum AST } \\
\quad(\mathrm{mg} / \mathrm{dl})\end{array}$ & $\begin{array}{l}\text { Serum ALT } \\
\quad(\mathrm{mg} / \mathrm{dl})\end{array}$ \\
\hline & Mean \pm SD & Mean \pm SD & Mean \pm SD & Mean \pm SD \\
\hline G1:Control negative (C-) & $6.10^{\mathrm{a}} \pm 1.04$ & $3.19^{\mathbf{a b}} \pm 0.00$ & $97.50^{\mathrm{d}} \pm 8.38$ & $43.52^{\mathrm{d}} \pm 3.23$ \\
\hline G2:Control positive $(\mathrm{C}+)$ & $5.32^{\mathrm{a}} \pm 0.27$ & $2.94^{\mathbf{b}} \pm 0.10$ & $153.62^{b} \pm 10.60$ & $75.07^{\mathrm{ab}} \pm 15.89$ \\
\hline G3:N.O.S 2\% & $6.51^{\mathrm{a}} \pm 0.79$ & $3.60^{\mathrm{a}} \pm 0.22$ & $124.20^{c} \pm 11.54$ & $69.29^{\mathrm{bc}} \pm 11.26$ \\
\hline G4:N.O.S 4\% & $6.40^{\mathrm{a}} \pm 0.52$ & $3.30^{\mathbf{a b}} \pm 0.31$ & $214.06^{\mathrm{a}} \pm 15.61$ & $83.24^{\mathrm{a}} \pm 2.37$ \\
\hline G5:O.S.P. 5\% & $5.96^{\mathrm{a}} \pm 1.03$ & $3.43^{\mathrm{a}} \pm 0.53$ & $128.33^{\mathrm{c}} \pm 13.47$ & $57.72^{c} \pm 4.41$ \\
\hline G6:O.S.P. $10 \%$ & $6.05^{\mathrm{a}} \pm 0.63$ & $3.24^{\mathbf{a b}} \pm 0.19$ & $120.72^{c} \pm 10.64$ & $58.82^{\mathrm{c}} \pm 7.89$ \\
\hline F. Value & 1.191 & 2.517 & 46.22 & 10.098 \\
\hline Sig. & 0.352 & 0.068 & 0.000 & 0.000 \\
\hline
\end{tabular}

Data in table (8) showed the effect of olive seeds powder (OSP) and nanoparticles olive seeds (NOS) on serum concentrations of Total protein, Albumin, AST, and ALT in obese hypercholesterolemic rats. It could be observed that AST and ALT was significantly increased in rats suffering from hepatic damage (positive control group) with a mean value of $153.62^{\mathrm{b}} \pm 10.60 \& 75.07^{\mathrm{ab}} \pm 15.89 \mathrm{U} / \mathrm{L}$ compared with the negative control group with a mean value of $97.50^{\mathrm{d}} \pm 8.38 \& 43.52^{\mathrm{d}} \pm 3.23 \mathrm{U} / \mathrm{L}$ respectively. In addition, it revealed that rats were fed on hyperlipidemic diet supplemented with olive seeds powder OSP by different levels 5\% \& $10 \%$ and nanoparticles of olive seeds NOS2\% had significant decrease in the serum AST and ALT when compared with the positive control group except in group (4) which rats fed on hypercholesterolemic diet supplemented with NGS 4\%. Also, the lowest reduction value of AST were found in group (6) when rats fed on hypercholesterolemic diet supplemented with GSP $10 \%$ and ALT were found in group (5)when rats fed on hypercholesterolemic diet supplemented with GSP $5 \% 120.72^{\mathrm{c}} \pm 10.64 \& 57.72^{\mathrm{c}} \pm 4.41 \mathrm{U} / \mathrm{L}$ respectively .

Moreover, from the same data, it could be observed that markedly decreased was recorded in total protein and albumin for rats fed on hypercholesterolemic diet without supplementation (positive control group ) with a mean value $5.32^{\mathrm{bc}} \pm 0.27 \& 2.94^{\mathrm{b}} \pm 0.10 \mathrm{mg} / \mathrm{dl}$ compared with the negative 
The Impact of Olive Seeds (Olea europaea L.) Powder (OSP) and its Nanoparticles (NOS) on Obese Hyperlipidemic Rats.

control group with a mean value $6.10^{\mathrm{ab}} \pm 1.04 \& 3.19^{\mathrm{ab}} \pm 0.00 \mathrm{mg} / \mathrm{dl}$ respectively . In addition, it could be revealed that significant and markedly increased in total protein and albumin were recorded for rats fed on hypercholesterolemic diet supplemented with olive seeds powder OSP(5\%\&10\%) and nanoparticles of olive seeds $\operatorname{NOS}(2 \% \& 4 \%)$ when compared with the positive control . The results agreement with El-Denshary, E.S., et al. (2015) who concluded that both chitosan nanoparticles (CNPs) and quercetin $(\mathrm{Q})$ could induce protection against hepatotoxicity. Consequently, CNPs was a promise candidate as drug delivery in liver diseases treatments.

\section{Conclusions}

It can be concluded that nanoparticles isolated from olive seeds had a significant positive effects against obesity and Hyperlipidemic than the effects of olive seeds Powder. Hence, the study may be repeated on patients with hyperlipidemia for possible beneficial effect on humans.

\section{REFERENCES}

Allain, C.C., L.S. Poon and C.S .G. Chan, (1974): Enzymatic determination of total serum cholesterol.Clinical Chemistry, 20(4):470-475.

Armitage, P. and Berry, G. (1987): Statistical method in medical research Blackwell, oxford, UK, pp, 93-213.

Aruoma, OI. (2003): Methodological considerations for characterizing potential antioxidant actions of bioactive components in plant foods. Mutation Research-Fundamental and Molecular Mechanisms of Mutagenesis 523, 9-20.

Bianchi, G. (2003): Lipids and phenols in table olives. Eur. J. Lipid Sci. Technol. 105, 229-242.

Brenes, M., García, A., García, P., Rios J.J . and Garrido A. (1999): Phenolic compounds in Spanish olive oil. J. Agric. Food Chem. 47, 3535-3540.

Burstein M., H.R. Scholnick, and R. Morfin,(1970):Rapid method for the isolation of lipoproteins from human serum by precipitation with polyanions,J.Lipid res.,11(6),583-595.

Carmen Veciana-Galindo, Ernesto Cortés-Castell, Luis Torró-Montell , Antonio Palazón-Bru , Elia Sirvent-Segura1, María M. Rizo-Baeza and Vicente F. Gil-Guillén .(2015): Antiadipogenic activity of an olive seed extract in mouse fibroblasts. Nutr Hosp.31 (6):2747-2751.

Chapman, D.; Gastilla, R. and Campbell, J. (1959): Evaluation of protein in food 1-A method for the determination of protein efficiency ratio. Can. J. Biochem. Physiol., 37:679-686.

Charoenprasert S. and Mitchell A. (2012): Factors influencing compounds in table olives (Olea europaea). J Agric Food Chem, 60: 7081 - 7095.

De la Torre-Carbort K., Jauregui O., Gimeno E., Castellote A.I., Lamuela-Raventós R.M. and López-Sabater M.C. (2005): Characterization and quantification of phenolic compounds in olive oils by solid-phase extraction, HPLC-DAD, and HPLC-MS/MS. Journal of Agricultural and Food Chemistry 53: 4331-4340.

El-Denshary, E.S., et al. (2015): Possible Synergistic Effect and Antioxidant Properties of Chitosan Nanoparticles and Quercetin against Carbon Tetrachloride-Induce Hepatotoxicity in Rats. Soft Nanoscience Letters, 5, 36-51. http://dx.doi.org/10.4236/snl.2015.52005.

Fabiani, R., De Bartolomeo, A., Rosignoli, P. , Servili, M., Montedoro, G.F., Morozzi, G. (2002): Cancer chemoprevention by hydroxytyrosol isolated from virgin olive oil through G1 cell cycle arrest and apoptosis. Eur. J. Cancer Prevention. 11, 351-358.

Fossati P.C., and Prencipe, (1982): Triglycerides determination after enzymatic hydorolysis, Clin.Chem.,28,20-77.

Goupy, P., Hugues, M.,Boivin P.,and Josephe M. A.,(1999):Antioxidant composition and activity of barley (Hordeum Vulgare) and malt extracts and of isolated phenolic compounds.J.Sci Food Agric 79:1625-1634.

FriedwEstiald ,W.T., R. I. Levy, and D.S. Fredrickson, (1972): Estimation of the concentration of low density lipoprotein cholesterol in plasma, without use of preparative ultracentrifuge, Clin.Chem., 18(6),499-502. 
GUI Yu,LU Hong-jia,ZHANG Duan-li, et al.(2014): Hypolipidemic Effects of Different Particle Sizes of Cellulose from Sweet Potato Residue in Ovariectomized Hyperlipidemia Rats[J]. Food Science, 2014, 35(5): 218-222.

Hao, J., Shen, W., Yu, G., Jia H., Li, X., Feng, Z .,(2010): Hydroxytyrosol promotes mitochondrial biogenesis and mitochondrial function in 3T3-L1 adipocytes. J Nutr Biochem 21: 634-44.

Hegsted, D.M., McGandy, R.B., Myers, M.L., (1965): Quantitative effects of dietary fat on serum cholesterol in man. Am J Clin Nutr.17:281-295.

Howard, B.V., Hannah, J.S., Heiser, C.C., (1995): Polyunsaturated fatty acids result in greater cholesterol lowering and less triacylglycerol elevation than do monounsaturated fatty acids in a dose-response comparison in a multiracial study group. Am J Clin Nutr. 62:392-402.

Jacomelli, M., Pitozzi, V., Zaid, M., Larrosa, M., Tonini, G., Martini, A .,(2010): Dietary extravirgin olive oil rich in phenolic antioxidants and the aging process: long-term effects in the rat. $\mathbf{J}$ Nutr Biochem 21: 290-6.

Jensen, S.R., Franzyk, H., Wallander, E., (2002): Chemotaxonomy of the Oleaceae: iridoids as taxonomic markers. Phytochemistry 60, 213-231.

Keys, A., (1965): Effects of different dietary fats on plasma-lipid levels. Lancet.17:318-319.

Liu Shaohua and Li. Yunong (2016): effect of nano sweet potato residue cellulose on blood glucose level of athletes. Carpathian Journal of Food Science and Technology 2016, 8(3), 13-21.

Lowry, O.H., Rosebrough, N.J., Farr, A.L., Radall, R.J.,(1951): Protein measurement with the Folin phenol reagent. J. Biol. Chem. 193, 265-267.

Maestro-Durán, R., Cabello, L.R,, Gutiérrez, R.V. and Roncero, V.A., (1994): Glucósidos fenólicos amargos de las semillas del olivo (Olea europaea). Grasas y Aceites 45, 332-335.

Mattila, P., Astola, J., and Kumpulainen, J., (2000): Determination of flavonoids in plant material by HPLC with diode-array and electro-array detections.J.Agric Food Chem., 48, 5834-5841.

Mensink RP, Katan M.B., (1992): Effect of dietary fatty acids on serum lipids and lipoproteins. A meta-analysis of 27 trials. Arterioscler Thromb. 12: 911-919.

Mohammad Asif1, (2013): Biological Significance of Seed Oil and Polyphenolic of Ole europaea. International Journal of Herbal Medicine, p. 28:41; 2321-2187.

Owen, R.W., Mier, W., Giacosa, A., Hull, W.E., Spiegelhalder, B., Bartsch, H.,( 2000):Phenolic compounds and squalene in olive oils: the concentration and antioxidant potential of total phenols, single phenols, secoiridoids, lignans and squalene. Food and Chemical Toxicology 38, 647-659.

Pérez, A.G., Luaces, P., Rios, J.J., Garcia, J.M., and Sanz, C., (2003): Modification of volatile compound profile of virgin olive oil due to hot-water treatment of olive fruit J. Agric. Food Chem 51, 6544-6549.

Robards, K., Prenzler, P.D., Tucke, G., Swatsitang, P., and Glover, W., (1999): Phenolic compounds and their role in oxidative processes in fruits. Food Chemistry 66: 401- 436.

Roy, E., (1970): Colorimetric determination of Co. St Louis. Toronto. Princeton. Pp. 1088-1273.

Ryan, D., Antolovich, M., Prenzler, P., Robards, K., and Lavee, S., (2002): Biotransformations of phenolic compounds in Olea europaea L. Sci. Hortic. 92, 147-176.

Reeves, P., F.H., Nielsen, and G. Fahmy, (1993): AIN-93. Purified diets for laboratory rodents: Final report of the American Institute of Nutrition adhoc wriling committee on the reformulation of the AIN-76 A Rodent diet. J. Nutrition, 123: 1939-151.

Servili, M., Baldioli, M., Selvagini, R., Macchioni, A., and Montedoro, G., (1999): Phenolic compounds of olive fruit: on e- and two-dimensional nuclear magnetic resonance characterization of nüzhenide and its distribution in the constitutive parts of fruit. J. Agric. Food Chem. 47, 12-18.

Servili, M., and Montedoro, G., (2002): Contribution of phenolic compounds in virgin olive oil quality. European Journal of Lipid Science and Technology 104: 602-613.

Servili, M., Selvaggini, R., Esposto, S., Taticchi, A., Montedoro, G., and Morozzi, M., (2004): Health and sensory properties of virgin olive oil hydrophylic phenols: agronomic and technological aspects of production that affect their occurrence in the oil. Journal of Chromatography A 1054: 113-127. 
The Impact of Olive Seeds (Olea europaea L.) Powder (OSP) and its Nanoparticles (NOS) on Obese Hyperlipidemic Rats.

Sherwin, J. (1984): Liver Function .In Kaplan LA,Pesce AJ,eds.Clinical chemistry ,theory, analysis,and correlation.St Louis: Mosby 55(25):420-438.

Visioli, F., Grande, S., Bogani, P., Galli, C., (2004): The role of antioxidants in the Mediterranean diets: focus on cancer. Eur. J. Cancer Prevention 13, 337-343.

Visioli, F., Caruso, D., Grande, S., Bosisio, R., Villa, M., Galli, G., Sirtori, C., Galli, C., (2005): Virgin Olive Oil Study (VOLOS): vasoprotective potential of extra virgin olive oil in mildly dyslipidemic patients. European Journal of Nutrition 44, 121-127.

Wise, L.E., Murphy, M., and D'Addieco, A.A., (1946): Chlorite holocellulose, its fractionation and bearing on summative wood analysis and on studies on hemicelluloses', Paper Trade Journal, $122(2), 35-43$.

Young, D., (1990): Effect of drugs on clinical laboratory tests. Am. J. Clin. Pathol 3(7):6-12.

Young, D.S., (1995): Effects of Drugs on Clinical Laboratory Tests, 4th Ed. Washington, DC; AACC.

Zhong Q Wang; Yongmei Yu; Xian H Zhang; Z Elizabeth Floyd; Anik Boudreau; Kun Lian and William T Cefalu (2012): Comparing the effects of nano-sized sugarcane fiber with cellulose and psyllium on hepatic cellular signaling in mice. International Journal of Nanomedicine 2012:7 2999-3012. 